\title{
Exploration of questioning strategy in college English class
}

\author{
Song $\mathrm{Hu}$
}

\author{
School of foreign languages, Dalian Jiaotong University, Dalian, 116021, China
}

Keywords: college English teaching; classroom questioning; questioning strategy

\begin{abstract}
English study serves as foreign language learning. The classroom becomes the main teaching situation. Based on English classroom teaching reality, this paper proposes classroom questioning strategies for college English teaching classroom questioning (such as rational distribution of the proportion of reference problems and display problems, reasonable distribution of questioning range, flexible mastery of the waiting time fior questioning and giving proper and active evaluation and feedback) according to the second language teaching and foreign language teaching theory and in combination of research results of educational psychology.
\end{abstract}

\section{Introduction}

Since foreign language learning breaks away from native language context reality and classroom serves as a main learning situation of foreign language learners, classroom questioning becomes a teaching strategy widely adopted in English teaching. It not just provides large quantities of English language input for students through classroom interactions, but also promotes students to actively think in English and organize language output. Moreover, teachers can gain feedbacks from classroom questioning, further know students; language mastery situation and provide effective reference for succeeding in organizing classroom teaching. So, it is required to boost questioning quality, give full play to questioning function and cultivate students' ability of oral expression in English. English classroom questioning strategy is very beneficial to optimizing classroom teaching. This paper plans to put forward corresponding rational suggestions from the perspective of questioning strategy in allusion to problems in teachers' questioning in college English class.

\section{Connotation of classroom questioning in English teaching}

In a broad sense, questioning refers to all verbal behaviors with questioning form or questioning function. According to the definition of classroom questioning put forward by E.C.Wragg in Classroom teaching skills, any which can trigger classroom verbal response is classroom questioning. Therefore, classroom questioning is a teaching form of designing questions according to teaching purpose and learning situation in teaching process.

Through classroom questioning, teachers can create English language situation, control teaching process and enhance teaching contents. Besides, students can gain second language input process, think actively and cultivate the ability to analyze, summarize and express in English. So, how to boost classroom questioning effectiveness in allusion to problems in college English classroom questioning deserves out attention.

\section{Problems in college English classroom questioning}

During investigations of college English classroom questioning, many problems are found: the number of students who are very willing to answer teachers' questions is very small, which is closely related to questioning quality; students are passive for teachers' questions, this is because teachers' questions are unevenly distributed and teachers do not well grasp the waiting time, which is closely related to teachers' questioning ways; besides, the survey on students; classroom anxiety and silence shows students' passivity in classroom questioning is closely related to timely feedback and evaluation after teachers' questioning. 


\section{Questioning strategy of college English class}

Since Chinese college English teaching breaks away from English native language, classroom becomes the major place for teachers to guide students to learn English. Furthermore, as Dell Hymes proposed the concept of "communicative competence", communication teaching starts to be widely applied in foreign language teaching field. The rising interactive teaching advocates important significance of interactions in class on second language acquisition. Therefore, teachers' questioning plays a great role in arousing students to think actively, organizing the target language, actively participating in classroom conversation and outputting the target language. In classroom teaching interactions, teachers' guiding function is more important, for teachers' problem design, questioning mode, analysis of questioning object and feedbacks will influence students' enthusiasm for English study. So, discussion on classroom questioning strategy has great significance for students’ English acquisition and English teaching.

(I) To rationally design problems according to students’ English level

Students' different English levels will directly influence the degree of receiving English, the quantity and quality if outputting English. Long \& Stato find English teachers mostly use "exhibition-type" problems in teaching, i.e. the questions to which questioners have known the answers, less use "reference-type" questions, i.e. the questions to which questioners have not known the answers. But Nunan's further study shows when teachers raise "reference-type" questions, language complexity increases. So, for the students with poor English foundation, this increases their anxiety and discourages their English output enthusiasm to some extent. However, since these questions more approach the language used in natural environment, for the students with good English foundation, this enhances the correlation among native language - Chinese and foreign language - English interlanguage and contributes to their language output. Therefore, to rationally design questions according to students' English level is of great importance for students to output language actively and interestingly.

From the perspective of development direction, if a non-fluent leaner with correct language has more opportunities to confront English speakers, they will gradually tend to be fluent. But a learner who seemingly has fluent English with many mistakes, it is difficult for him to develop at a correct way by his own acquisition, for her has formed the wrong habits he considers right and formatted some of his wrong expression patterns. Nobody gives directions to him, or some give directions to him, but he does not think so. How to turn the wrong to the right?

(II) To see problems from development direction

During discussing poor communication ability of Chinese learners, people often impute to teaching language knowledge (i.e. grammar). In fact, this censure is one-sided and makes no contribution to improving teaching quality. In my view, poor communication ability of Chinese learners depends on multiple factors. For example, English as foreign language acquisition is different from English as second language acquisition; listening in China and foreign language speaking environment have many limitations; the adoption of original communicative approach has very high requirements for teachers, while existing qualified teachers or experienced teachers are few. Most Chinese students are introverted in terms of character. Other factors include inferior hardware and openness degree. All these show to improve communicative competence is a comprehensive project. Grammar teaching cannot solve the problem. The view of Hu Zhuanglin is quite good in this aspect.

(III) To cultivate students' good questioning habit

To make learning methods effective, it is required to cultivate students' good habits. Good learning habit is the precondition and necessary guarantee for students to master effective earning methods. We can start from the following to cultivate students' good learning habit:

1. To formulate plans

To learn well, firstly, it is required to a feasible learning plan to guide one's study. The ancients said, "Preparedness ensures success and unpreparedness spells failure." With a plan, one can rationally arrange time and properly allocate his energy. With a plan, one can have the leanring objective, learning motivation and striving direction. Teachers should guide students to formulate 
long-range objectives, cognize small objectives for each lesion or each unit according to different subjects, and make students continuously motivated by objectives, learn actively and improve learning efficiency.

2. Self-study before class

Self-study before class is the foundation for students to learn new lesions well and gain efficient learning results. If self-study before class is not done well, students will not have clear aims and fail to grasp the main points. On the contrary, if self-study before class is done well, students can not just cultivate their self-study ability (the ability to think independently), but also can improve their interest in improving learning interest and master learning initiative. Through self-study before class, students can discover difficulties, think, reduce blindness and enhance learning effects. Under the precondition of learning to learn, self-study before class should change word memorization and text reading. We require students to consult the dictionary, remember example sentences, make sentences with new words, imitate typical expression methods, interpret sentences, find out difficulties in texts, learn English in the process of fully utilizing textbooks and ensure self-study degree before class. In particular, we should pay attention to whether students rally master the self-study methods and guide them with certain purpose.

3. To attend class intently

Classroom is a channel to implement quality-oriented education. Attending class is a basic skill for students to understand and master basic knowledge and also a key link to develop cognitive ability. Students are required to always keep highly centralized attention, think actively, be keenly alert, actively cultivate conscious attention, consciously memorize new words, phrases, sentence patterns, key sentences and strive to remember the most important learning contents in class.

4. To take notes diligently

In the 18tj century, famous writer Samuel Johnson called taking notes “necessary pains”. Taking notes is a painful thing, but is very necessary. Notes are permanent and systematic records and are very important for reviewing the knowledge learned and overcoming the limitation of memory storage in minds. The process of taking notes is the process of information screening and concentration and contributes to training thinking and improving the ability to capture important information and concentrate information. To take notes well, students' thinking process and the teacher's thinking process must be consistent. Students must throw off distracting thoughts. The contents of the notes should focus on key points, difficult points, doubtful points and new views. Students can concentrate on the main points with key words and clue sentences.

During extracurricular reading, students also should take some notes briefly, which greatly contributes to deepening comprehension, consolidating and accumulating knowledge as well as cultivating learning ability.

5. To review in time

Timely review after class can deepen and consolidate comprehension and memory of new knowledge, and promote students to systematically master new knowledge and reach the purpose of flexible application. Therefore, "timely review" must be mastered in order to reach scientific and efficient study. Psychological study shows indicates students can forget the knowledge learned rapidly in a short time and then the forgetting speed slows down. So, review must be timely and conducted on the day. Review includes after-class review, stage review, mid-term and final-term review. Review should combine disperse review and collective review. Disperse review has better effects than collective review, but collective review is also essential. During review, students can first try to recall, then read teaching materials repeatedly and master key contents through the notes and memory.

\section{To practice repeatedly}

Language is learned in use. Communicative competence can be gained the most effective training and cultivation only in communication. Teachers should guide students to strive for various training opportunities to practice repeatedly in order to improve their English level, such as practicing English and cultivating real communicative competence in class, after class and at English corner. 


\section{References}

1. English Readings in Education, Li Kongzhen

2. Exploration of Language ProblemS, Wang Zongyan, Shanghai Foreign Language Education Press, 1985

3. Linguistics Course, Hu Zhuanglin et al., Shandong University Press, 1989 